\title{
MAKANAN ETNIK MELAYU: TEMPOYAK
}

\author{
Amanda Haruminori ${ }^{1}$, Nathania Angelia ${ }^{2}$, Andrea Purwaningtyas ${ }^{3}$

\begin{abstract}
Traditional food is considered as one of the identities that makes a nation, and it is caused by the varieties of cultures. Tempoyak (asam durian) is one of the examples of traditional foods, specifically for the Malayan ethnic, and it is widely known in Palembang. The majority of Palembang citizens are known to be nomads, and since durians are abundant in Sumatra, food processing is done to increase shelf life. Tempoyak is the result of fermenting durian for 3-7 days by adding salt into the fruit. Fermentation is one of the many ways of food processing. The fermentation of durian gives tempoyak a unique flavour that combines sourness from the fermentation process and sweetness from the fruit itself. Fermentation is one of the most wellknown food processing in Indonesia, and has been known for years. To the Malayan ethnics, tempoyak has a unique taste that can increase ones appetite, and it is usually used as a complementary food for rice, and also spices. One of the foods that use a tempoyak spices is brengkes.
\end{abstract}

Keywords: fermentationi,traditional food, tempoyak

\begin{abstract}
Abstrak
Makanan tradisional merupakan salah satu identitas negara yang dipengaruhi oleh berbagai budaya. Tempoyak merupakan salah satu makanan tradisional hasil diaspora etnik Melayu yang terkenal di Sumatra dan Malaysia. Tempoyak merupakan salah satu makanan tradisional etnik Melayu yang terkenal di Palembang. Mayoritas masyarakat Palembang adalah perantau, dan karena buah durian sangat melimpah di Palembang, maka dilakukan pengolahan buah tersebut sehingga dapat tahan lama. Tempoyak merupakan hasil fermentasi buah durian selama 3-7 hari dengan penambahan garam. Fermentasi adalah salah satu proses pengolahan makanan awetan. Hasil fermentasi ini memberikan tempoyak rasa yang unik yaitu perpaduan antara asam hasil fermentasi dan manis buah durian. Fermentasi merupakan salah satu pengolahan pangan yang sudah melekat dan menjadi budaya di Indoesia sejak dahulu. Bagi masyarakat etnik Melayu, tempoyak memilik rasa unik yang dapat meningkatkan nafsu makan dimana tempoyak merupakan makanan pelengkap nasi dan juga bumbu. Salah satu makanan dengan bumbu tempoyak adalah brengkes.
\end{abstract}

Kata-kata Kunci: fermentasi, makanan tradisional, tempoyak

\footnotetext{
${ }^{1}$ Jurusan Teknologi Pangan, Universitas Surya, Email: aharuminori@gmail.com

2 Jurusan Teknologi Pangan, Universitas Surya

3 Jurusan Teknologi Pangan, Universitas Surya
} 


\section{A. PENDAHULUAN}

$\mathrm{D}$ iaspora etnik Melayu ke berbagai daerah seperti Sumatra dan Malaysia memberikan hubungan sejarah dan pengaruh budaya yang kuat, salah satunya adalah budaya makanan. Adanya diaspora ini memberikan kemiripan makanan tradisional antara Sumatra dan Malaysia (Rahman, 2017). Salah satu makanan yang serupa antara Sumatra dan Malaysia adalah tempoyak. Tempoyak adalah makanan hasil fermentasi daging buah durian dan meruapakan makanan yang sangat digemari oleh masyarakat etnik Melayu. Tidak heran masyarakat Sumatra bagian Selatan antara lain Jambi, Lampung dan Palembang menyukai jenis makanan ini (Venus dan Dahlan, 2015)

Fermentasi merupakan salah satu metode pengolahan makanan yang sudah ada dari zaman dahulu (Rahman, 2017). Fermentasi buah durian terjadi secara spontan dengan bantuan asam laktat sehingga dapat memperpanjang umur simpan (Yulianan, 2004). Palembang merupakan salah satu daerah yang sangat terkenal dengan budaya fermentasi. Durian yang sangat berlimpah sehingga dilakukan pembudidayaan. Tempoyak merupakan makanan pendamping nasi atau dapat digunakan sebagai bumbu makanan olahan lain seperti tempoyak ikan patin atau brengkes (Ahmad, 2017 dan Rahman, 2017). Bagi masyarakat etnik Melayu, makan dengan tempoyak memberikan cita rasa yang enak dan sebagai penggugah selera (van der Burg, 1904).

Makanan entik Melayu ini sangat digemari oleh masyarakat Sumatra umumnya di bagian selatan dan menjadi ciri khasnya. Pada artikel ini akan menberikan gambaran mengenai tempoyak di Sumatra bagian Selatan yaitu Palembang dan fermentasi yang terjadi.

\section{B. METODE}

$\mathrm{M}$ etode penulisan artikel ini yaitu dengan studi literatur dan wawancara kepada narasumber yang tepat dan berhubungan dengan topik yang diangkat.

\section{MAKANAN KHAS}

$\mathrm{M}$ akanan khas adalah makanan unik dimana tidak ada di daerah lain atau umum makanan tersebut ditemukan di daerah tertentu serta cita rasa makanan tersebut diterima oleh masyarakat tersebut. Dalam pembuatan makanan khas daerah, peranan budaya sangat mempengaruhi. Budaya yang umum mempengaruhi adalah etnik dan kebiasaan makan. Golongan entik ini umumnya menyukai rasa, tekstur dan aroma makanan tersebut (Rahman, 2017).

\section{ETNIK MELAYU}

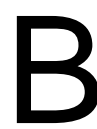
erdasarkan Kamus Besar Bahassa
Indonesia etnik adalah bertalian
dengan kelompoksosial dalam kebudayaan yang mempunya arti tertenti karena keturunan, adat, agama, Bahasa dan sebagainya. Menurut Darity (2005), etnik adalah kelompok yang berbeda dari kelompok yang lain dalam suatu masyarakat dilihat dari aspek budaya. Budaya sendiri sangat dipengaruhi oleh sejarah dan nenenk moyang. Karena turn temurun ini maka suatu kegiatan yang dilakukan akan menjadi tradisi turn temurun (Ratclife, 2006). Dengan demikian secara umum dapat dikatakan bahwa etnik memiliki ciri khas budaya yang dipengaruhi oleh berbagai macam aspek sejarah.

Etnik Melayu merupakan kelompok etnik Malaysia (Malaysua Barat dan sekitar Malaysia timur) dan pulau-pulau yang berdekatan di Asia Tenggara yaitu Sumatra, Klimantan dan beberapa pulau kecil diantara. Etnik melayu adalah masyarakat Borneo yang berdiaspora atau berkembang ke Sumatra dan Malaysia karena memiliki budaya pencaharian yaitu berdangan dan berlayar (Venus dan Dahlan, 2015).

Dengan adanya penyebaran ini maka akan timbulnya budaya-budaya mereka yang terbawa dan kemudian muncul budaya perpaduan antara etnik Melayu dan masyarakat daerah yang mereka datangi.

\section{E. SEJARAH TEMPOYAK}

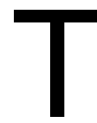

empoyak merupakan salah satu makanan khas Sumatra umumnya bagian Selatan. Secara definisi, nama tempoyak diserap dari teknik pengolahan 
makanan yaitu dari kata poyak sehingga dapat dikatakan nama tempoyak didapatkan karena cara pengolahan durian yaitu mengoyak (Rahman, 2017) atau mencabik (Anonim, 2017). Berdasarkan Hikayat Abdullah, pada tahun 1836, beliau mendatangi Terengganu dan menemukan makanan berbau tidak sedap namun disenangi oleh masyarakat etnik Melayu yaitu Tempoyak. Dikatakan dalam catatan perjalanan Abdullah bin Abdulkadir Munsyi ini, masyarakat tersebut sangat menggemari tempoyak dan mengatakan bahwa tempoyak sebagai penggugah selera makan (Sweeney, 2006).

Tempoyak merupakan bagian dari kuliner Sumatra yang sangat populer di Palembang. Palembang merupakan wilayah produsen durian terbesar di Sumatra (Purnama, 2014). Alfred Wallace mengatakan bahwa durian meruapakan king of fruit di daerah Palembang karena jumlahnya yang sangat berlimpah. Menurut catatan perjalanan Abdullah bin Abdulkadir Munsyi dan Alfred Wallace pada awal abad 19, mereka mengatakan bhawa tempoyak memiliki bau yang tidak sedap dan memabukkan. Berbeda dengan masyarakat etnik Melayu, menurut mereka tempoyak adalah makanan pelengkap penggugah selera, penambah cita rasa pada makanan (Rahman, 2017 dan Sweeney, 2006).

Merantau merupakan budaya yang melekat pada masyarakat Sumatra. Bagi masyarakat Sumatra merantau adalah hal yang umum dilakukan. Pada masa lalu, merantau merupakan salah satu cara untuk mata pencaharian (Rahman, 2017). Disaat merantau, para perantau perlu mempersiapkan perbekalan maka tidak mengherankan makana-makanan khas
Sumatra umumnya berdasar pada pengo lahan makanan menjadi makanan awetan. Salah satunya adalah tempoyak.

\section{F. FERMENTASI TEMPOYAK}

$\mathrm{P}$ engolahan makanan bertujuan untuk mengawetkan makanan dan memberikan cita rasa unik pada makanan. Fermentasi merupakan salah satu cara pengolahan makanan yang sudah ada sejak zaman dahulu. Hampir sebagian besar makanan nusantara juga menggunakan metode ini dalam pengolahan makanan kas daerah. Proses fermentasi ini juga berperan dalam membantu makanan agar memiliki umur simpan yang cukup lama.

Seperti yang sudah diketahui, tempoyak merupakan hasil fermentasi daging durian.yang melibatkan bakteri asam laktat dengan adanya penambahan sedikit garam. Fermentasi yang terjadi pada pembuatan tempoyak berjalan secara spontan. Fermentasi spontan terjadi selama 2-7 hari (Leisner et al. 2001.) dan hasil fermentasi ini akan memberikan padatan semisolid dengan aroma asam yang kuat (Yuliana et al. 2011).

Fermentasi tempoyak dilakukan dalam wadah tertutup. Secara tradisional pembuatan tempoyak serupa dengan pembuatan kimchi. Fermentasi dilakukan pada wadah yang terbuat dari tanah liat dan di peram dalam tanah (Rahman, 2017). Namun seiring dengan berkembangnya zaman, dapat menggunakan wadah lain seperti toples. Fermentasi ini akan menghasilkan cita rasa unik perpaduan antara asam dari hasil fermentasi dan manis dari buah durian.

\begin{tabular}{llr}
\hline No. & Komposisi & Persentase \\
\hline $\mathbf{1}$ & Abu & $2.0 \%$ \\
$\mathbf{2}$ & Kelembaban & $67.0 \%$ \\
$\mathbf{3}$ & Keasaman & $3.6 \%$ \\
$\mathbf{4}$ & Brix & $38.7 \%$ \\
$\mathbf{5}$ & Total Gula & $4.5 \%$ \\
$\mathbf{6}$ & Garam & $1.3 \%$ \\
$\mathbf{7}$ & Serat Kasar & $2.5 \%$ \\
$\mathbf{8}$ & Lemak & $1.4 \%$ \\
\hline
\end{tabular}


Diketahui bahwa tempoyak merupa kan makanan pendamping nasi dan juga sebagai bumbu untuk membuat jenis makanan lainnya (Rahman, 2017). Brengkes merupakan salah satu makanan yang menggunakan tempoyak sebagai bumbu utama. Brengkes memiliki arti kata yang sama dengan pepes yaitu salah satu pengolahan dengan cara pengukusan. Merupakan masakan tradisional Sumatra Selatan dengan kombinasi ikan patin dan durian berserta rempah-rempah. Rasa yang dihasilkan yaitu perpeduan antara asam, manis, gurih dan pedas (Ahmad, 2017).

\section{G. KESIMPULAN}

$\mathrm{T}$ empoyak meruapakan makanan sehari-hari masyarakat etnik Melayu dan sudah menjadi budaya dikarenakan jumlah durian yang melimpah di Palembang. Tempoyak terbuat dari buah durian yang difermentasikan dengan garam selama 2-7 hari. Bagi masyarakat etnik Melayu, tempoyak memiliki peranan penting sebagai pelengkap makanan mereka dan juga sebagai salah satu cara pengawetan makanan sehingga memiliki umur simpan yang panjang. Rasa unik perpaduan antaran manis dan asam membuat tempoyak memberikan sensai sebagai penggugah selera bagi mereka. Selain sebagai makanan pendamping nasi, tepoyak juga dapat digunakan sebagai bumbu seperti pada brengkes.

\section{DAFTAR PUSTAKA}

Anonim. (2017). Diakses: Oktober 29, 2017, Arti kata - Kamus Besar Bahasa Indonesia (KBBI) Online: http://Kbbi.web.id

Burg, C. L. (1904). De Voeding in Nederlandsch-Indië. J.H. de Bussy.

Darity Jr, W. A. (2005). International Encyclopedia of the Social Science (2 ed., Vol. 3). New York: Macmillan Reference.

Ido, A. (2017). Brengkes Tempoyak, Menyatukan Ikan dan Durian ke dalam Satu Hidangan. Retrieved from IndonesiaKaya: http://www.indonesiakaya.com/jelajahindonesia/detail/brengkes-tempoyak-menyatukan-ikan-dan-durian-ke-dalam-satuhidangan,

Leisner, J. .. (2001). Identification of lactic acid bacteria constituting the predominating microflora in an acid-fermented condiment (tempoyak) popular in Malaysia. International Journal of Food Microbiology, 63(1-2), 149-157.

N Yuliana, E. I. (2011). The effect of spontaneous fermentation on the volatile flavor constituents of durian. Int J Food Res(18), 635-641.

Pengantar ke Arah Filsafat Konumikasi Etnik Melayu . (2015). In M. A. Antar Venus, Filsafat komunikasi orang Melayu (pp. 8-16). Bandung: Simbiosa Rekatama Media.

Purnama, Y. (2014). Formulir Pencatatan Warisan Budaya Tak Benda: Tempoyak. Kementrian Pendidikan dan Kebudayaan Republik Indonesia.

Rahman, F. (2017, November 24). Sejarah Tempoyak. (N. A. Amanda Haruminori, Interviewer) Bandung.

Ratcliffe, P. (2006). Conceptualizing "Race", Ethnicity and Nation: Towards a Comparative Perspective. London: Taylor and Francise .

Setiawan, D. (2011). Formulir Pencatatan Warisan Budaya Tak Benda: Tempoyak. Kementrian Pendidikan dan Kebudayaan Republik Indonesia.

Steinkraus, K. H. (1995). Handbook of indigenous fermented foods. (2, Ed.) Taylor \& Francis.

Sweeney, A. (2008). Karya lengkap Abdullah bin Abdul Kadir Munsyi. Kepustakaan Populer Gramedia.

Wallace, A. R. (1869). The Malay Archipelago. Macmillan Publisher.

Yuliana, N. (2004). Biochemical changes in fermented durian. 